【論文】

\title{
円筒形鋼管矢板井筒基礎の解析 ANALYSIS OF CYLINDRICAL SHEET PILE FOUNDATION
}

\author{
駒田敬一* - 岡原美知夫** - 高 尾 孝二*** - 倉 方慶夫**** \\ By Keiichi KOMADA, Michio OKAHARA, Kohji TAKAO \\ and Yoshio KURAKATA
}

\section{1. まえがき}

鋼管矢板井筒基礎（以下，鋼管井筒とよぶ）は，施工 上の有利性から近年実施例が増えつつあるが，設計上の 問題点が少なからず残されている発展途上の基礎形式と いえよう。

実施例のほとんどは，建設技術研究補助金の対象とな った「矢板式基礎の施工性と構造特性に関する研究」の ために組織された矢板式基礎研究委員会からの刊行にな る「矢板式基礎の設計と施工指針」)に則って設計され ている.この指針の設計計算法は，おもに実物載荷試験 を基礎としたいわば実験式であって，各矢板が重ねばり 的挙動を示す鋼管井筒全体を 1 本の棒に置き換えて計算 するものであるので, 構造特性を十分に表現し得るもの とはいいがたい。 また基礎となった実物載荷試験は比較 的小規模であり，その数も少ないため，指針の設計計算 法にはおのずと適用限界があると考えねばならない，

費用のかかる実物載荷試験に代わって, 浅い土槽内で の小さい模型実験によって鋼管井筒の構造特性を解明し よらとする試み2) 出も行われているが，これでは寸法効 果の影響が顕著に現われ, 実構造物の挙動を定量的に把 握することは困難のようである.

このようなことから, 最近では鋼管井筒の挙動を計算 で追跡しようとする試みも行われている，その一例とし て文献 5) では地盤や継手の塑性化も考慮に入れた計算 を行い，貴重な資料を提供している.しかし，そこでは 地盤を三次元の有限要素に分割し，また各矢板を線材に 置き換えて，鋼管井筒の構造を表現するものであるの で，かなり膨大な計算量を要するものと思われる.

\footnotetext{
* 正会員 工修 建設省地方道課市町村道室長

** 工 修 科学技術庁計画局国際科学技術博覧会推進室 室 長補佐

*** 正会員 新日本技研 (株) 取締役

**** 正会員 工博 新日本技研 (株)
}

本報告で試みた解析法は計算量をより少なくすること を目標とし，文献 6)に示した解析法を拡張して新たに 誘導したものであり，これを既往の実物載荷試験 ${ }^{7 \sim 10)} に$ 適用して検証を行ってみたが，鋼管井筒の構造特性を比 較的よく表現し得るものと思えたので，ここに報告する 次第である.

まず，この解析におけりる基本的な計算前提を以下に記 す.

i ） 鋼管井筒の断面は円形とし, 井筒を構成する各 矢板の断面は等しく，等間隔に配置されている.

ii ） 井筒径に比べ矢板間隔は十分小さい.

iii）井筒の断面は図一1の $Y$ 軸に関し対称であり, 変位と変形も $Y$ 軸に関し対称に生ずる. すなわ ち, 井筒および地盤の支持機構や外力は $Y$ 軸に 関し対称である。

iv）地盤は分布ばねに置換して扱うことができる.

以下，井筒の変位場と応力場の基本式を求め，ついで 数值計算を行らが, 個々の場における計算仮定はその都 度記すことにする。

\section{2. 鋼管井筒の变位場}

この章では鋼管井筒の変位場の構成を行うが，まず井 筒全体を連続体である円筒シェルと仮想して変位場を構 成する. 次に, 矢板の中心軸がその仮想円筒シェルに固 定されているとして, 離散的に配置された個々の矢板の 変位場を求める.

\section{（1）仮想円筒シェルの変位場}

井筒の断面上で矢板の中心点を連ねる円曲線を井筒周 長線とよぶことにする. 図一1 に示すように，2組の右 手系座標 $(X, Y, z)$ と $(s, n, z)$ 座標 を導入する. $(X, Y, z)$ 座標は直交直線座標である. $(s, n, z)$ 座標 の $s$ 軸は井筒周長線に沿う座標であり, $n$ 軸は $s$ 軸の 


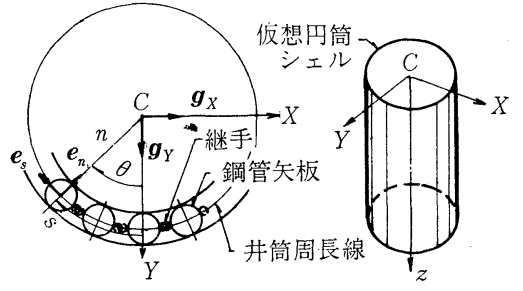

図一1 井筒と座標

縦法線方向の直線軸とする.

井筒周長線を $z$ 軸方向に連ねた円筒面を仮想円筒シェ ルの中央面とよぶが，この節ではこの中央面の変位場を 扱 .

$(s, n, z)$ 座標における，仮想円筒シェル中央面上の 変位前の基本ベクトルを $\boldsymbol{e}_{s}, \boldsymbol{e}_{n}, \boldsymbol{e}_{z}$ と表わすと,

$$
\left.\begin{array}{l}
\left|\boldsymbol{e}_{s}\right|=\left|\boldsymbol{e}_{n}\right|=\left|\boldsymbol{e}_{z}\right|=1 \\
\boldsymbol{e}_{s} \cdot \boldsymbol{e}_{n}=\boldsymbol{e}_{n} \cdot \boldsymbol{e}_{\boldsymbol{z}}=\boldsymbol{e}_{z} \cdot \boldsymbol{e}_{s}=0
\end{array}\right\} \cdots \cdots \cdots \cdots \cdots(1 \cdot \mathrm{a}, \mathrm{b})
$$

である. 中央面上の変位べクトルを $u^{*}$ とし，

$\boldsymbol{u}^{*}=\xi^{*} \boldsymbol{e}_{s}+\eta^{*} \boldsymbol{e}_{n}+\zeta^{*} \boldsymbol{e}_{\boldsymbol{z}}$

と表わす. また, 井筒周長線の曲率半径を $r^{*}$ とし, 曲 率を $\kappa^{*}$ と表わす.

$$
\kappa^{*}=1 / r^{*}
$$

このとき, ベクトル $\boldsymbol{e}_{s}, \boldsymbol{e}_{n}$ の $s$ 座標による微分は,

$$
\partial \boldsymbol{e}_{s} / \partial s=\kappa^{*} \boldsymbol{e}_{n}, \partial \boldsymbol{e}_{n} / \partial s=-\kappa^{*} \boldsymbol{e}_{s}
$$

である.したがって， $(s, n, z)$ 座標を埋め込み座標と ᄂ,

$$
\theta=\kappa * s
$$

と表わすとき, 仮想円筒シェル中央面での変位後の基本 ベクトル $\hat{\boldsymbol{e}}_{s}, \hat{\boldsymbol{e}}_{\boldsymbol{z}}$ は次のようになる.

$$
\begin{aligned}
& \hat{\boldsymbol{e}}_{s}=\boldsymbol{e}_{s}+\partial \boldsymbol{u}^{*} / \partial s \\
& =\left\{1+\kappa^{*}\left(\frac{\partial \xi^{*}}{\partial \theta}-\eta^{*}\right)\right\} \boldsymbol{e}_{s}+\kappa^{*}\left(\frac{\partial \eta^{*}}{\partial \theta}+\xi^{*}\right) \boldsymbol{e}_{n} \\
& +\kappa^{*} \frac{\partial \zeta^{*}}{\partial \theta} \boldsymbol{e}_{z} \\
& \widehat{\boldsymbol{e}}_{z}=\boldsymbol{e}_{z}+\partial \boldsymbol{u}^{*} / \partial z \\
& =\frac{\partial \xi^{*}}{\partial z} \boldsymbol{e}_{s}+\frac{\partial \eta^{*}}{\partial z} \boldsymbol{e}_{n}+\left(1+\frac{\partial \zeta^{*}}{\partial z}\right) \boldsymbol{e}_{z} \cdot
\end{aligned}
$$

井筒周長線の伸張変形を $\varepsilon_{s}$ と表わすと,

$$
\left|\hat{\boldsymbol{e}}_{s}\right|=1+\varepsilon_{s}
$$

であり，また周長線の水平面内での角変位を $\varphi$ と表わ すと, 微小変位問題であるので変位, 変形に関する二次 項を無視して,

$$
\left.\begin{array}{l}
\hat{\boldsymbol{e}}_{s} \cdot \boldsymbol{e}_{n}=\left(1+\varepsilon_{s}\right) \sin \varphi \doteqdot \varphi \\
\hat{\boldsymbol{e}}_{s} \cdot \boldsymbol{e}_{s}=\left(1+\varepsilon_{s}\right) \cos \varphi \doteqdot 1+\varepsilon_{s}
\end{array}\right\} \cdots \cdots \cdots(7 \cdot \mathrm{a}, \mathrm{b})
$$

となる.上式に式 (5) を代入し,

$$
\varphi=\kappa^{*}\left(\frac{\partial \eta^{*}}{\partial \theta}+\xi^{*}\right), \varepsilon_{s}=\kappa^{*}\left(\frac{\partial \xi^{*}}{\partial \theta}-\eta^{*}\right)
$$

となる. ここで, 変位, 変形は $Y$ 朝に関して対称に生
ずるとし，

$$
\varphi=\sum_{k=1}^{K}\left(\varphi_{k} \sin k \theta\right), \varepsilon_{s}=\varepsilon_{0}+\sum_{k=1}^{K}\left(\varepsilon_{k} \cos k \theta\right)
$$

とおく. 今後, 三角級数の項数は添字 $k$ にて示すこと にする.シェルのような連続体では上式右辺は無限級数 で与えられるが，有限個の矢板から成る鋼管井筒では, 変位が $Y$ 軸に関し対称の場合, 項数 $K$ の最大值は $Y$ 軸上の矢板を除いた矢板本数の $1 / 2$ となる.

式（9）を式（5）に代入し積分を行うと，円周方向に 1 周したときの変位の連続条件から,

$$
\varphi_{1}=\varepsilon_{1}
$$

となり,また $Y$ 軸に関する対称性から積分定数を決定 すると， $\xi^{*}, \eta^{*}$ は次のように求まる.

$$
\begin{aligned}
\xi^{*}= & -V_{c} \sin \theta-r^{*} \sum_{k=2}^{K}\left(\varphi_{k} \frac{1}{k^{2}-1} \sin k \theta\right) \\
& +r^{*} \varepsilon_{1} \sin \theta+r^{*} \sum_{k=2}^{K}\left(\varepsilon_{k} \frac{k}{k^{2}-1} \sin k \theta\right) \\
& \cdots \cdots \cdots \cdots \cdots \cdots \cdots \cdots \cdots \cdots \cdots \cdots \cdots(11 \cdot \mathrm{a}) \\
\eta^{*}= & -V_{c} \cos \theta-r^{*} \sum_{k=2}^{K}\left(\varphi_{k} \frac{k}{k^{2}-1} \cos k \theta\right) \\
& -r^{*} \varepsilon_{0}+r^{*} \sum_{k=2}^{K}\left(\varepsilon_{k} \frac{1}{k^{2}-1} \cos k \theta\right) \cdots(11 \cdot \mathrm{b})
\end{aligned}
$$

ここに, 上式右辺第 1 項は井筒断面が変形せずに $Y$ 軸 方向に $V_{c}$ だけ変位する状態を表わしている. すなわ ち, 井筒全体が単一棒として働く状態を表わしている.

同様にして井筒の軸方向変位を求めるにつき, 仮想円 筒シェル中央面のせん断ひずみを次のように仮定する.

$$
r_{z s} *=\sum_{k=1}^{K}\left(r_{k} \sin k \theta\right)
$$

ここに, $\gamma_{k}$ は $\varphi_{k}, \varepsilon_{0}, \varepsilon_{k}$ などと同様に変位場のパラメー ターとなるものである. 円筒シェルの解析ではほとんど の場合, 変位場のパラメーターとして変位が用いられる が，ここでは剛体的変位以外はすべて変形量を用いてい る.

ところで仮想円筒 シェル中央面のせん断ひずみ $\gamma_{z s}{ }^{*}$ は,

$$
r_{z s} *=\hat{\boldsymbol{e}}_{z} \cdot \hat{\boldsymbol{e}}_{s}=\frac{\partial \xi^{*}}{\partial z}+\frac{\partial \zeta^{*}}{\partial s}
$$

で与えられるから，上式に式 (11・a)，(12) を代入し， $s$ に関して積分すると, 仮想円筒シェル中央面の $z$ 方向 変位が次のように求まる.

$$
\begin{aligned}
\zeta^{*}= & W_{c}-V_{c}^{\prime} r^{*} \cos \theta-r^{* 2} \sum_{k=2}^{K}\left\{\varphi_{k}{ }^{\prime} \frac{1}{k\left(k^{2}-1\right)} \cos k \theta\right\} \\
& -r^{*} \sum_{k=1}^{K}\left(r_{k} \frac{1}{k} \cos k \theta\right)+r^{* 2}\left\{\varepsilon_{1}^{\prime} \cos \theta+\sum_{k=2}^{K}\right. \\
& \left.\cdot\left(\varepsilon_{k}{ }^{\prime} \frac{1}{k^{2}-1} \cos k \theta\right)\right\} \ldots \ldots \ldots \ldots \ldots \ldots \ldots \ldots \ldots \ldots \ldots \ldots \ldots \ldots \ldots
\end{aligned}
$$

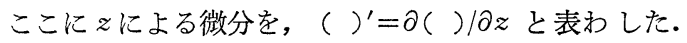
また, $W_{c}$ は井筒断面の剛体的な軸方向変位を表わす積 
仮想円筒シェルの断面

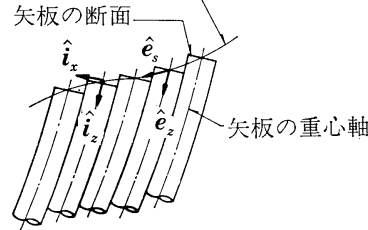

図一2 仮想円筒シェルと矢板の 関係

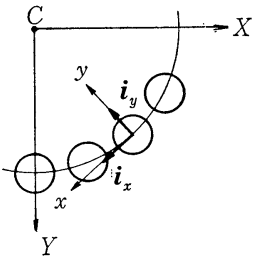

図一3 矢板の局所 座標
分定数である.

\section{（2）個々の矢板の変位場}

個々の矢板の変位場を求めるにつき，それらの重心軸 は仮想円筒シェル中央面に結合されており，ともに同じ 変位をすると考える．また個々の矢板は通常の棒理論に 従うものと仮定する. この結果，図一2 に示すように仮 想円筒シェルの断面は連続した曲線であるのに対し，鋼 管井筒の断面は一般に矢板が相互にずれて階段状にな る.

図一3 に示すように，個々の矢板に対し局所直交直線 座標 $(x, y, z)$ を導入して矢板 (i) の変位場を記述す る.このとき $x, y$ 座標の原点は矢板の重心軸上にある とする.

矢板 $(i)$ の 局所座標 $(x, y, z)$ の基本 ゙゙クトルを $\left(\boldsymbol{i}_{x}\right)_{i},\left(\boldsymbol{i}_{y}\right)_{i},\left(\boldsymbol{i}_{z}\right)_{i}$ と表わすとき,

$$
\left.\begin{array}{l}
\left(\boldsymbol{i}_{x}\right)_{i}=\boldsymbol{e}_{s}\left(\theta=\theta_{i}\right), \quad\left(\boldsymbol{i}_{y}\right)_{i}=\boldsymbol{e}_{n}\left(\theta=\theta_{i}\right) \\
\left(\boldsymbol{i}_{\boldsymbol{z}}\right)_{i}=\boldsymbol{e}_{z}
\end{array}\right\}
$$

であるとする.ここに $\theta_{i}$ は矢板 $(i)$ の重心軸の $\theta$ 座 標であり，( $)_{i}$ は括弧内の量が矢板 $(i)$ あるいは次節 で述べる継手 (i) に関する諸量であることを表わしてい る、ただし，特に必要がない場合は（）ｉを省略するこ とがある。

ここで, 矢板 $(i)$ の重心軸の変位ベクトルを

$$
\left(\boldsymbol{u}_{0}\right)_{i}=\left(u_{0} \boldsymbol{i}_{x}+v_{0} \boldsymbol{i}_{y}+w_{0} \boldsymbol{i}_{z}\right)_{i}
$$

と表わすと，先に述べた前提により，

$$
\left.\begin{array}{l}
\left(u_{0}\right)_{i}=\xi^{*}\left(\theta=\theta_{i}, z\right), \quad\left(v_{0}\right)_{i}=\eta^{*}\left(\left(\theta=\theta_{i}, z\right)\right. \\
\left(w_{0}\right)_{i}=\eta^{*}\left(\theta=\theta_{i}, z\right)
\end{array}\right\}
$$

である. 矢板 $(i)$ の一般点での変位ベクトルを

$$
(\boldsymbol{u})_{i}=\left(u \boldsymbol{i}_{x}+v \boldsymbol{i}_{y}+w \boldsymbol{i}_{z}\right)_{i}
$$

と表わすと，個々の矢板の断面は変位後も平面を保持し 矢板の重心軸に直交するとした通常の棒理論に従うとし ているので,

$$
\left.\begin{array}{l}
(u)_{i}=\left(u_{0}-y \varphi_{0}\right)_{i},(v)_{i}=\left(v_{0}+x \varphi_{0}\right)_{i} \\
(w)_{i}=\left(w_{0}-x u_{0}{ }^{\prime}-y v_{0}{ }^{\prime}\right)_{i}
\end{array}\right\}
$$

である.ここに,

$$
\left(\varphi_{0}\right)_{i}=\varphi\left(\theta=\theta_{i}, z\right)
$$

である.これにより矢板 $(i)$ の一般点でのひずみ成分 は，

$$
\left.\begin{array}{l}
\left(\varepsilon_{z}\right)_{i}=(\partial w / \partial z)_{i}=\left(w_{0}^{\prime}-x u_{0}^{\prime \prime}-y v_{0}^{\prime \prime}\right)_{i} \\
\left(r_{z x}\right)_{i}=(\partial u / \partial z+\partial w / \partial x)_{i}=\left(-y \varphi_{0}{ }^{\prime}\right)_{i} \\
\left(r_{z y}\right)_{i}=(\partial v / \partial z+\partial w / \partial y)_{i}=\left(x \varphi_{0}^{\prime}\right)_{i}
\end{array}\right\}
$$

となり，他のひずみ成分は零である.

\section{（3） 継手間のずれ変位と角変位}

継手の構造には，たとえば図一1に示すように鋼管を かみ合せ，その中にモルタルを充填するものなどいくつ かの形式があるが，ここ ではそれらをモデル化し て図一4に示すように継 手を点で表わす．継手は $x$ 軸上にあるものとし， 継手と矢板重心間の距離 をb/2 とする.

矢板には $s$ 座標の増 す方向に順次番号を付け て, 矢板 $(i)$ と矢板 $(i+$ 1)の間の継手を継手 $(i)$ とすると，この継手 $(i)$ のずれ変位 $(\Delta w)_{i}$ は,
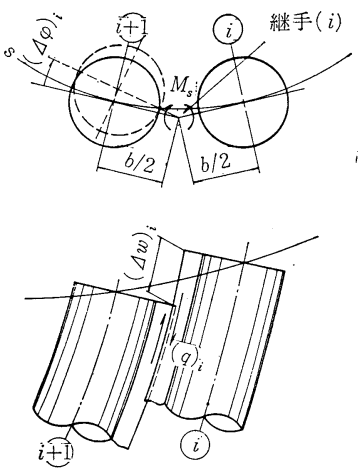

図一4継手のずれ変位と角変位

$$
\begin{aligned}
(\Delta w)_{i}= & \{w(x=-b / 2, y=0, z)\}_{i+1} \\
& -\{w(x=b / 2, y=0, z)\}_{i}
\end{aligned}
$$

となる．上式に式 $(19 \cdot c) ，(17)$ を介して式 (11)，(14) を代入すると，

$$
\begin{aligned}
(\Delta w)_{i}= & -r^{*} \sum_{k=1}^{K}\left\{\frac{1}{k}\left(f_{k}^{(1)}\right)_{i} r_{k}\right\} \\
& -r^{* 2} \sum_{k=2}^{K}\left\{\frac{1}{k\left(k^{2}-1\right)}\left(f_{k}{ }^{(2)}\right)_{i} \varphi_{k}{ }^{\prime}\right\} \\
& +r^{* 2} \sum_{k=2}^{K}\left\{\frac{1}{k^{2}-1}\left(f_{k}{ }^{(2)}\right)_{i} \varepsilon_{k}{ }^{\prime}\right\}_{i} \ldots
\end{aligned}
$$

となる．ここに，

$$
\left.\begin{array}{rl}
\left(f_{k}^{(1)}\right)_{i} & =\{\cos (k \Delta \theta)-1\} \cos k \theta_{i}-\sin (k \Delta \theta) \sin k \theta_{i} \\
\left(f_{k}^{(2)}\right)_{i} & =\left\{\cos (k \Delta \theta)-1+\frac{b}{2 r^{*}} k \sin (k \Delta \theta)\right\} \cos k \theta_{i} \\
- & {\left[\sin (k \Delta \theta)-\frac{b}{2 r^{*}} k\{\cos (k \Delta \theta)+1\}\right] \sin k \theta_{i}}
\end{array}\right\}
$$

であり，矢板間隔は等間隔とし矢板本数を $n_{p}$ とすると き

$$
\Delta \theta=\theta_{i+1}-\theta_{i}=2 \pi / n_{p}
$$

と表わした．また， $\theta_{i}$ は前節と同様に矢板 $(i)$ の中心 軸の $\theta$ 座標である.このような継手のずれ変位のほか に，式 (20) で与えられている矢板断面の回転変位によ り，図一4 に破線で示したように継手 $(i)$ に次の $(\Delta \varphi)_{i}$ なる角変位が生ずる. 


$$
(\Delta \varphi)_{i}=\left(\varphi_{0}\right)_{i+1}-\left(\varphi_{0}\right)_{i}=\sum_{k=1}^{K}\left\{\left(f_{k}^{(1)}\right)_{i} \varphi_{k}\right\}
$$

\section{(4) 矢板の断面変形}

仮想円筒シェルの周長線の 伸張変形に対応するものは, 継手にゆるみがないものとす れば，図一5 に示すような矢 板の断面変形 $\Delta d$ である. 継 手間隔が井筒の周長に比べ十 分小さいとすれば, 矢板 (i)

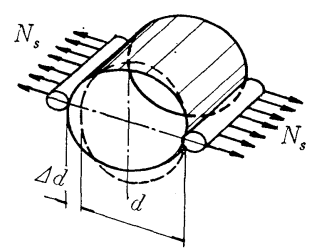

図一5 矢板の断面変形 の断面変形 $(\Delta d)_{i}$ 核次のようになる.

$$
\begin{aligned}
(\Delta d)_{i} & =\int_{\theta_{i}-\Delta \theta / 2}^{\theta_{i}+\Delta \theta / 2} \varepsilon_{s} r^{*} d \theta \\
& =r^{*}\left[\varepsilon_{0} \Delta \theta+2 \sum_{k=1}^{K}\left\{\frac{1}{k} \varepsilon_{k} \sin \frac{k \Delta \theta}{2} \cos k \theta_{i}\right\}\right]
\end{aligned}
$$

\section{3. 地盤の抵抗}

井筒内外の地盤は水平 2 方向 打よび鉛直方向に抵抗すると考 えられるが、ここではこれらを ケーソン基礎の設計で行われて いると同様に弾性床に置き換え が可能と仮定する．ただし計算 上は地盤反力の合力は個々の矢 板の中心軸働くとして扱らの で図一6に示すように個々の矢 板の中心軸上に分布する地盤ば 数を仮定し次のように表わす。

$$
\left.\begin{array}{l}
\left(p_{r s}\right)_{i}=\left(k_{s}\right)_{i} \cdot\left(u_{0}\right)_{i} \\
\left(p_{r n}\right)_{i}=\left(k_{n}\right)_{i} \cdot\left(v_{0}\right)_{i} \\
\left(p_{r z}\right)_{i}=\left(k_{z}\right)_{i} \cdot\left(w_{0}\right)_{i}
\end{array}\right\}
$$

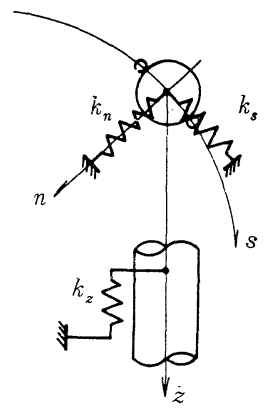

図一6地盤ばね
ここに, $p_{r s}, p_{r n}, p_{r z}$ は個々の矢板の中心軸上に分布 乙て作用する $\boldsymbol{i}_{x}, \boldsymbol{i}_{y}, \boldsymbol{i}_{z}$ 方向の地盤反力である. $k_{s}, k_{n}$, $k_{z}$ は個々の矢板の中心軸上に分布するそれぞれの方向 の地盤ばねであり，その強さは井筒の深さ方向にも，ま た周方向にも（各矢板ごとに）変化するとして扱う．

上記の式 (27) は太短い井 筒を考えた場合は井筒の外側 と内側地盤の抵抗値の合計と 考えてよいが，たとえば特に 細長い井筒を考えるとき，井 筒内部地盤が外部地盤と同様 に井筒の全体的な剛体変位 $V_{c}$ に抵抗するとは考えられ ず, 内部地盤は井筒の断面変

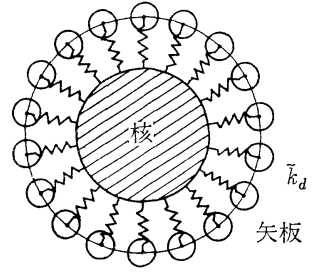

図一7 井筒の断面変形に 対する内部地盤の ばね
形のみに抵抗すると考えられる，そのため，別途に井筒 の断面变形にのみ抵抗する地盤ばねを考えておく.すな わち, 図一7 に示すようにモデル化し, 井筒の軸方向に 無数に独立した薄い核を考え，この核と個々の矢板が $\boldsymbol{i}_{\boldsymbol{y}}$ 方向の分布ばね $\tilde{k}_{d}$ で結ばれているものと考える. 地 盤ばね $\tilde{k}_{d}$ は先の地盤ばねと同様に矢板の中心軸上に作 用する分布ばねであるが, 深さ方向云の強度は変化す るものの井筒の周方向には一定とする. また, 核は矢板 と地盤ばね $\tilde{k}_{d}$ で結ばれている以外には何の拘束む受け ないとするしたがって核に㗢くばね反力の合力は零で あり，この状態に対する地盤反力は個々の矢板に対して 次のようになる.

$$
\left(\tilde{p}_{r d}\right)_{i}=\tilde{k}_{d}\left(v_{0 d}\right)_{i}
$$

ここに $\left(v_{0 d}\right)_{i}$ は式 $(11 \cdot \mathrm{b})$ の $\eta^{*}$ から井筒断面の剛体 的変位成分 $V_{c}$ を除いたものであり,

$$
\begin{aligned}
\left(v_{0 d}\right)_{i}= & -r^{*} \sum_{k=2}^{K}\left(\varphi_{k} \frac{k}{k^{2}-1} \cos k \theta_{i}\right)-r^{*} \varepsilon_{0} \\
& +r^{*} \sum_{k=2}^{K}\left(\varepsilon_{k} \frac{1}{k^{2}-1} \cos k \theta_{i}\right) \ldots \ldots \ldots . .
\end{aligned}
$$

である。

このほか, 図一8に示す 井筒内部地盤のせん断抵抗 も考えることにする. 井筒 すなわち，仮想円筒シェル 中央面のせん断変形は式 (12) で与えられるが，こ

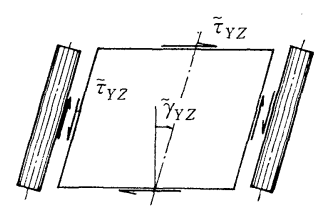

図一8 井筒内部地盤の せん断抵抗
のような井筒のせん断変形に伴い井筒内部の土もせん断 変形すると考える. しかし井筒内部の土が式 (12) の $k$ $\geqq 2$ に対忘する高次のせん断変形モードで変形すると は考えにくいので， $k=1$ のせん断変形モードだけを考 える5).

このとき，井筒内部土のせん断ひずみは $(X, Y, z)$ 座標で表わすと次のようである.

$$
\tilde{r}_{Y z}=-r_{1}
$$

したがって, 内部地盤のせん断弾性係数を $\tilde{G}$ とすると, 内部土に生ずるせん断応力は，

$$
\tilde{\tau}_{Y z}=\tilde{G} \tilde{\gamma}_{Y z}=-\tilde{G} r_{1}
$$

となる・

\section{4. 仮想仕事の原理への適用}

外力を受けっり合いを保っている井筒に対し仮想仕事 の原理は次のように表わされる。

$$
\begin{aligned}
& \int_{z_{1}}^{z_{2}} \sum_{i}\left\{\int_{A_{p}}\left(\sigma_{z} \delta \varepsilon_{z}+\tau_{z x} \delta r_{z x}+\tau_{y z} \delta r_{y z}\right) d A_{p}\right. \\
& +N_{s} \delta(\Delta d)+\left(p_{r s} \delta u_{0}+p_{r n} \delta v_{0}+p_{r z} \delta w_{0}\right) \\
& \left.\quad+\tilde{p}_{r d} \delta v_{0 d}\right\}_{i} d z+\int_{z_{1}}^{z_{\mathrm{q}}} \sum_{i}\left\{q \delta(\Delta \omega)+M_{s} \delta(\Delta \varphi)\right\}_{i} d z
\end{aligned}
$$




$$
\begin{aligned}
& +\int_{z_{1}}^{z_{2}} \int_{\tilde{A}} \tilde{\tau}_{Y z} \delta \tilde{Y}_{Y z} d \tilde{A} d z-\int_{z_{1}}^{z_{2}} \sum_{i}\left\{p_{s} \delta u_{0}+p_{n} \delta v_{0}\right. \\
& \left.+p_{z} \delta w_{0}\right\}_{i} d z-\left[\nu _ { z } \sum _ { i } \left\{\int_{A_{p}}\left(\bar{p}_{s} \delta u+\bar{p}_{n} \delta v+\bar{p}_{z} \delta w\right)\right.\right. \\
& \left.\left.\cdot d A_{p}\right\}_{i}+\nu_{z} \int_{\tilde{A}} \bar{p}_{Y} \delta V_{c} d A\right]_{z_{1}}^{z_{2}}=0 \cdots \cdots \cdots \cdots(32)
\end{aligned}
$$

ここに, $\sum_{i}\{\}_{i}$ は \{\} 内の個々の矢板あるいは継手に 関する量の総和を表わす.また, $\int_{A_{p}} d A_{p}$ は個々の矢板 の断面について, $\int_{\tilde{A}} d \tilde{A}$ は井筒内部地盤の断面につい ての積分を表わす. その他の記号については次のようで ある。

\section{$z_{1}, z_{2}:$ 井筒両端の $z$ 座標}

$\sigma_{z}, \tau_{z x}, \tau_{z y}$ : 局所座標 $(x, y, z)$ で定義される, 個 々の矢板断面に働く応力

$N_{s}:$ 矢板働 $<$ 井筒の周方向応力 (図一5)

$q, M_{s}:$ 継手に働くせん断志力とモーメント

\section{(図一)}

$\tilde{\tau}_{Y z}:$ 井筒内部地盤のせん断応力 (図一8)

$p_{s}, p_{n}, p_{z}$ : 個々の矢板の中心軸敒分布して作用す る外力の $i_{x}, i_{y}, i_{z}$ 方向成分

$\bar{p}_{s}, \bar{p}_{n}, \bar{p}_{z}$ : 個々の矢板の両端断面に分布して作用 する外力 (表面力) の $i_{x}, i_{y}, i_{z}$ 方向 成分

$\bar{p}_{Y}:$ 井筒内部地盤の両端断面に分布して作 用する外力 (表面力) の $g_{Y}$ (図一1) 方向成分

$\nu_{z}:$ 井筒両端断面の外向き単位法線ベクト ルの $\boldsymbol{e}_{z}$ 方向成分

井筒断面は $z$ 軸に直交しているので, $z_{2}>z_{1}$ のとき

$$
\nu_{z}=\left\{\begin{array}{rr}
-1, & \left(z=z_{1}\right) \\
1, & \left(z=z_{2}\right)
\end{array}\right.
$$

である。

式（32）に式 (21)，(30) を代入し, 各矢板について,

$$
\left.\begin{array}{rl}
N_{p} & =\int_{A_{p}} \sigma_{z} d A_{p} \\
M_{x p} & =\int_{A_{p}} \sigma_{z} x d A_{p}, M_{y p}=\int_{A_{p}} \sigma_{z} y d A_{p} \\
T_{s p} & =\int_{A_{p}}\left(\tau_{z x} y-\tau_{z y} x\right) d A_{p} \\
\cdots \cdots \cdots \ldots \ldots \ldots . . . & \\
\bar{Q}_{x p} & =\int_{A_{p}} \bar{p}_{x} d A_{p}, \bar{Q}_{y p}=\int_{A_{p}} \bar{p}_{y} d A_{p} \\
\bar{N}_{p} & =\int_{A_{p}} \bar{p}_{z} d A_{p} \\
\bar{M}_{x p} & =\int_{A_{p}} \bar{p}_{z} x d A_{p}, \bar{M}_{y p}=\int_{A_{p}} \bar{p}_{z} y d A_{p} \\
\bar{T}_{p} & =\int_{A_{p}}\left(\bar{p}_{x} y-\bar{p}_{y} x\right) d A_{p}
\end{array}\right\}
$$$$
(34 \cdot a \sim d)
$$

と表わし, 井筒内部地盤については,

$$
\begin{aligned}
& \tilde{Q}_{E}=\int_{\tilde{A}} \tilde{\tau}_{Y z} d \tilde{A} . \\
& \bar{P}_{Y}=\int_{\tilde{\mathbb{A}}} \bar{p}_{Y} d \tilde{A} .
\end{aligned}
$$

と表わすとき，式（32）は次のようになる.

$$
\begin{aligned}
& \int_{z_{1}}^{z_{2}} \sum_{i}\left\{N_{p} \delta w_{0}^{\prime}-M_{x p} \delta u_{0}^{\prime \prime}-M_{y p \delta} \delta v_{0}^{\prime \prime}+T_{s p} \delta \varphi_{0}^{\prime}\right. \\
& \quad+N_{s} \delta(\Delta d)+p_{r s} \delta u_{0}+p_{r n} \delta v_{0}+p_{r z} \delta w_{0} \\
& \left.\quad+\tilde{p}_{r d} \delta v_{0}\right\}_{i} d z+\int_{z_{1}}^{z_{2}} \sum_{i}\left\{q \delta(\Delta w)+M_{s} \delta(\Delta \varphi)\right\}_{i} d z \\
& \quad-\int_{z_{1}}^{z_{2}} \tilde{Q}_{E} \delta r_{1} d z-\int_{z_{1}}^{z_{2}} \sum_{i}\left\{p_{s} \delta u_{0}+p_{n} \delta v_{0}+p_{z} \delta w_{0}\right\}_{i} d z \\
& \quad-\left[\nu _ { z } \sum _ { i } \left\{\bar{Q}_{x p} \delta u_{0}+\bar{Q}_{y p} \delta v_{0}+\bar{N}_{p} \delta w_{0}-\bar{T}_{p} \delta \varphi_{0}\right.\right. \\
& \left.\left.\quad-\bar{M}_{x p} \delta u_{0}^{\prime}-\bar{M}_{y p} \delta v_{0}^{\prime}\right\}_{i}+\nu_{z} \bar{P}_{Y} \delta V_{c}\right]_{z_{1}}^{z_{2}}=0
\end{aligned}
$$

上式に式（17）を介して式（11）（14）を代入，さら に式 (23)，(25)，(26)，(29）も代入して変位パラメー ター $V_{c}, W_{c}, \varphi_{k}, r_{k}, \varepsilon_{0}, \varepsilon_{k}$ に関して部分積分を遂行す ると被積分項の変分量の係数から微小井筒要素 $(z=$ const. と $z+d z=$ const. の平面で 図一1 の井筒を輪切 りにしたときの長さ $d z$ の井筒）のつり合い式が求ま る. また, 境界項の変分量の係数加ら学的境界条件 が求まる.しかし，このよ5にして求まるつり合い式は 複雑な微分方程式となり, それから直接的に解を求める ことは困難であり，本報告では解を求めるにこれを用い ず後に示す近似解法によっているので，その表記は省略 する．また，境界条件は解法によらず必要なものである が,これも表記が長くなるため省略する．ただ，本報告 における直応力に関する境界条件の内力項は一般化力を 表わすが，これは後に参照するので，井筒断面力のうち の一般化力のみ次に記述しておく.

$$
\begin{aligned}
& N=\sum_{i}\left(N_{p}\right)_{i} \\
& (39 \cdot a) \\
& M_{Y}=-\sum_{i}\left\{r_{0} N_{p} \cos \theta-M_{x p} \sin \theta-M_{y p} \cos \theta\right\}_{i} \\
& B_{k}^{(\varphi)}=-\frac{r_{0}}{k^{2}-1} \sum_{i}\left\{\frac{r_{0}}{k} N_{p} \cos k \theta-M_{x p} \sin k \theta\right. \\
& \left.-k M_{y_{p}} \cos k \theta\right\}_{i},(k=2 \sim K) \cdots(39 \cdot \mathrm{c}) \\
& B_{k}(r)=\frac{r_{0}}{k} \sum_{i}\left(N_{p} \cos k \theta\right)_{i},(k=1 \sim K) \\
& B_{0}^{(\varepsilon)}=r_{0} \sum_{i}\left(M_{y p}\right)_{i} \\
& B_{1}^{(\varepsilon)}=r_{0} \sum_{i}\left(r_{0} N_{p} \cos \theta-M_{x p} \sin \theta\right)_{i} \cdots(39 \cdot f) \\
& B_{k}^{(\varepsilon)}=\frac{r_{0}}{k^{2}-1} \sum_{i}\left(r_{0} N_{p} \cos k \theta-k M_{x p} \sin k \theta\right. \\
& \left.-M_{y p} \cos k \theta\right)_{i},(k=2 \sim K) \cdots(39 \cdot \mathrm{g})
\end{aligned}
$$




\section{5. 応カと変位の関係}

鋼管矢板材のヤング係数とせん断弾性係数をそれぞれ $E, G$ と表わすと, 各矢板の応力と変位の関係は,

$$
\left.\begin{array}{l}
\sigma_{z}=E \varepsilon_{z}=E\left(w_{0}^{\prime}-x u_{0}^{\prime \prime}-y v_{0}^{\prime \prime}\right) \\
\tau_{z x}=G r_{z x}=-G y \varphi_{0}^{\prime} \\
\tau_{z y}=G r_{z y}=G x \varphi_{0}^{\prime}
\end{array}\right\}
$$

となる. 局所座標 $(x, y, z)$ の $x, y$ 軸は各矢板でその 断面主軸と一致しているものとすると，

$$
\int_{A_{p}} x d A_{p}=\int_{A_{p}} y d A_{p}=\int_{A_{p}} x y d A_{p}=0 \text {. }
$$

であるから, 式 (40) を式 (34) に代入し, 各矢板の断 面力と変位の関係は次のようになる。

$$
\begin{aligned}
& N_{p}=E A_{p} w_{0}{ }^{\prime}, M_{x p}=-E I_{x p} u_{0}^{\prime \prime} \\
& \left.M_{y p}=-E I_{y p} v_{0}^{\prime \prime}, T_{s p}=G J_{s} \varphi_{0}^{\prime}\right\}
\end{aligned}
$$

$(42 \cdot a \sim d)$

ここに, $A_{p}, I_{x p}, I_{y p}, J_{s}$ は矢板の断面定数であり,

$$
\left.\begin{array}{l}
A_{p}=\int_{A_{p}} d A_{p}, \quad I_{x p}=\int_{A_{p}} x^{2} d A_{p} \\
I_{y p}=\int_{A_{p}} y^{2} d A_{p}, \quad J_{s}=\int_{A_{p}}\left(x^{2}+y^{2}\right) d A_{p}
\end{array}\right\}
$$

である. 式 $(43 \cdot a \sim c)$ では一般に継手部の鋼材も含めた 矢板断面について積分するものとするが, 式 $(43 \cdot \mathrm{d})$ の $J_{s}$ の計算に㧹いては継手部は開断面であることから継 手を含めない矢板本管の断面について積分するものとす る.

継手のせん断応力 $q$ と継手のずれ変位 $\Delta w$ も弾性関 係にあるとして，各継手について，

$$
q=G_{J} \Delta w
$$

と表わす. ここに $G_{J}$ を継手のせん断剛度とよぶこと にする. 同様に継手のモーメント $M_{s}$ や矢板に㗢く井 筒周方向応力を次のように表わす.

$$
\begin{aligned}
& M_{s}=k_{\varphi} \Delta \varphi \\
& N_{s}=E_{s} \Delta d
\end{aligned}
$$

ここに， $k_{\varphi}$ は継手部の角変位 $\Delta \varphi$ に抵抗する回転ばね であり， $E_{s}$ は矢板の断面変形に対する剛度である（図 $-4,5)$.

井筒内部地盤の断面積を $\tilde{A}$ と表わすと, 式 (36) に 式（31）を代入して，

$$
\tilde{Q}_{E}=-\tilde{G} \tilde{A} r_{1}
$$

となる。

\section{6. 矢板の断面力}

ここでは, 式 $(34 \cdot \mathrm{a} \sim \mathrm{c})$ で定義した矢板の直応力に 関する断面力 $N_{p}, M_{x p}, M_{y p}$ と式 (39) の一般化力の
関係を求める.

式（39）に式 $(42 \cdot a \sim c)$ および式（17）を介して式 (11)，(14）を代入すると，一般化力を変位パラメータ 一で表現できる. その関係を逆変換して, 各変位パラメ 一ターを一般化力で表わした後, それを式 (42) に代入 すると個々の矢板の断面力と井筒全体断面の一般化力の 関係が次のように求まる.

$$
\begin{aligned}
N_{p}= & \frac{N}{n_{p}}-\sum_{k=1}^{K}\left(\frac{2 k B_{k}(r)}{n_{p} r_{0}} \cos k \theta\right) \\
M_{x p}= & -\frac{2}{n_{p} r_{0}}\left[\left(r_{0} B_{1}{ }^{(r)}+B_{1}{ }^{(\varepsilon)}\right) \sin \theta\right. \\
& +\sum_{k=2}^{K}\left\{\left(B_{k}{ }^{(\varphi)}+r_{0} B_{k}^{(r)}+k B_{k}^{(\varepsilon)}\right) \sin k \theta\right\} \\
M_{y p}= & \frac{2}{n_{p} r_{0}}\left[\frac{B_{0}^{(\varepsilon)}}{2}+\left(r_{0} M_{Y}+B_{1}^{(\varepsilon)}\right) \cos \theta\right. \\
& \left.+\sum_{k=2}^{K}\left\{\left(k B_{k}{ }^{(\varphi)}+B_{k}{ }^{(\varepsilon)}\right) \cos k \theta\right\}\right]
\end{aligned}
$$

ただし，上式を求める過程で，各矢板の断面定数は等し く, 矢板は等閒隔に配置されていることを前提として， 次の関係を用いた.

$$
\left.\begin{array}{l}
\sum_{i} \sin ^{2} k \theta_{i}=\sum_{i} \cos ^{2} k \theta_{i}=n_{p} / 2 \\
\sum_{i}\left(\sin k \theta_{i} \cdot \cos k \theta_{i}\right)=0
\end{array}\right\}
$$

\section{7. 数 值 解 法}

式（38）の部分積分を遂行すれば微小井筒要素につ いての応力表示のつり合い式が求められる. それに式 （48）などを代入して変位表示を行えば変位パラメータ 一に関する多元連立常微分方程式が求まるが, それを直 接解くことは困難である.

そこで, 本論文ではその近似解法として有限要素法を 用いた. すなわち, $z=z_{1}$ と $z=z_{2}\left(=z_{1}+\Delta l\right)$ のつの 平面で井筒を輪切りにしたときの長さ $\Delta l$ の井筒を有限 要素とし, 式 (38) から誘導される力学的境界条件に対 応する幾何学的境界条件を表現できる最低次のべき級数 で変位パラメーターの $z$ 方向モードを下記のように仮定 したものである.すでに式 (11)，(14）で周方向の変位 モードを三角級数で仮定しているので, 有限帯板法に類 似した手法といえよう。

変位パラメーターとしては, $V_{c}, W_{c}, \varphi_{k}, \gamma_{k}, \varepsilon_{0}, \varepsilon_{k},(k$ $=1 \sim K)$ とあるが，ここではこれらを代表して便宜的 に $\delta(z)$ と表わして本報告で用いた有限要素法の説明を 行う. 有限要素両端での変位パラメーターの值を

$$
\left.\begin{array}{l}
\delta_{1}=\delta\left(z_{1}\right), \delta_{2}=\delta\left(z_{2}\right) \\
\delta_{3}=l^{*} \delta^{\prime}\left(z_{1}\right), \delta_{4}=l^{*} \delta^{\prime}\left(z_{2}\right)
\end{array}\right\} \cdots \cdots \cdots \cdot(50 \cdot \mathrm{a} \sim \mathrm{d})
$$

とおく.ここに $l^{*}$ は任意の基準長である.また，

$$
\mu=\left(z-z_{1}\right) / \Delta l,\left(z_{1}<z<z_{2}\right)
$$


とおき, 補間関数として,

$$
\begin{aligned}
& \left.\begin{array}{l}
g_{1}=1-3 \mu^{2}+2 \mu^{3}, g_{2}=3 \mu^{2}-2 \mu^{3} \\
g_{3}=\mu-2 \mu^{2}+\mu^{3}, g_{4}=-\mu^{2}+\mu^{3}
\end{array}\right\} \\
& \text { …….......... (52.a d) } \\
& \tilde{g}_{1}=1-\mu, \tilde{g}_{2}=\mu
\end{aligned}
$$

を採用した.これらの補間関数を用いて, 先に述べた幾 何学的境界条件を満足しうる最低次のものとして, 本報 告では 1 つの有限要素内の変位パラメーターを, 変位パラメーター $V_{c}, \varphi_{k}, \varepsilon_{0}, \varepsilon_{k}$ に対しては,

$$
\delta(z)=\sum_{m=1}^{4}\left(g_{m} \delta_{m}\right)
$$

変位パラメーター $W_{c}, r_{k}$ に対しては,

$$
\delta(z)=\sum_{m=1}^{2}\left(\tilde{g}_{m} \delta_{m}\right)
$$

と表わしている.

この後, 式 (38) の応力や地盤反力などを式 (42), (44)〜 (47) および式 (27)，(28)，(31）などで変位表示 したものに式 (54) を代入し $z_{1} \sim z_{2}$ 間で積分を行えば, 各変位パラメーターの要素両端の節点変位, 式 (50)の $\delta_{m}$, の変分量の係数から 1 つの有限要素の剛性方程式が 求まる.これ以後は通常の岡性法と同じであり, 要素両 端の変位の連続条件により各有限要素の剛性方程式を結 合し境界条件の処理を行えば，節点変位を未知量とする 多元連立一次方程式の形で, 対象とする井筒全体の剛性 方程式が求まる.

解としての節点変位を各有限要素の剛性方程式に代入 し等価節点力の処理を行えば，式（38）から誘導される 力学的境界条件に対応する節点力が求まる. それには式 （39）に示す一般化力が含まれているので，式 (48) によ り各矢板の断面力が求まる. このほか, 各矢板の断面力 を求める方法として, 式 (54) を式 (42) に代入して各 矢板断面力と節点変位の関係を導き, それに求められた 節点変位を代入して 矢板断面力を計算する方法もある が，この方法では精度が低下するので注意を要する。

\section{8. 数値計算による鋼管井筒の性状に関する 考察}

実物載荷試験に適用する前に, ある1つの基準モデル を設定し，その諸定数を変化させて計算を行い，鋼管井 筒の性状について多少の考察をしておく.

\section{（1）基準モデルの設定}

図一9 に示す比較的太短い井筒を対象とし，その諸定 数は次の仮定のもとに計算を行った.

a) 地盤ばね

地盤反力係数はすべて道路橋示方書・下部構造編 ${ }^{11}$ を 準用して計算を行った. すなわち, 井筒中間地盤の水平

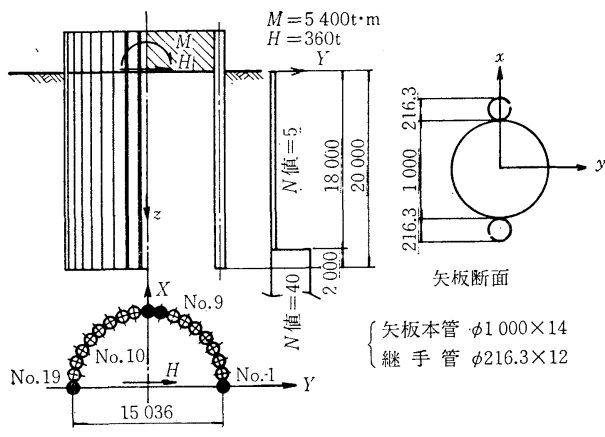

図一9 基準モデル

方向地盤反力係数 $K_{H}$ 打よび底面地盤の 鉛直方向地盤 反力係数 $K_{V}$ は, $N$ 值から地盤の変形係数を推定し, ついで道示 ${ }^{11} の 4.3$ に従って計算を行ったものである。 ただしその際, 基礎の換算載荷幅としては, 中間地盤の $K_{H}$ に対しては井筒外径 $\left(D+d_{p}, D=2 r^{*}, d_{p}\right.$ : 矢 板の外径) を, 底面地盤の $K_{V}$ に対しては $\sqrt{A_{V}}=$ $\sqrt{\pi D d_{p}}$ をあてた. また, $K_{H}$ の算出に際し道示 ${ }^{11)}$ でい 5 “側面の分担分 $20 \%$ ” は別途に地盤ばね $k_{s}$ として考 慮するので，これを含めないよう道示の式（解 7.5.3） では分子の 1.2 を 1 として計算を行ったものである. このようにして求めた $K_{H}, K_{V}$ を用いて式 (27) に示 す中間地盤の分布ばねは，各矢板 1 本当たり

$$
k_{n}=K_{H} \pi D / n_{p}, k_{s}=k_{z}=0.2 k_{n} \cdots \cdots \cdot(55 \cdot \mathrm{a}, \mathrm{b})
$$

と仮定し, 井筒底面における矢板 1 本当たりの地盤ばね は鉛直方向を $K_{z p}, \boldsymbol{i}_{x}, \boldsymbol{i}_{y}$ 方向のせん断地盤ばねをそれ ぞれ $K_{x p}, K_{y p}$ とするとき，

$$
K_{z p}=K_{V} A_{V} / n_{p}, K_{x p}=K_{y p}=K_{z p} / 3.5
$$

と仮定したものである. 各矢板に衔く地盤ばねは上記の ように周方向には一定とした，そのため, 地盤の圧縮面 にのみ地盤反力係数を仮定するケーソン基礎と比べ, 地 盤の水平抵抗を約 2 倍高く評価していることになる.

この基準モデルを含め，本報告の数值計算では鋼管井 筒の諸定数はすべて周方向に一定で，外力は剛な頂版を 介して井筒に伝達されるとする，その場合，変位パラメ 一ターのうち $V_{c}, W_{c}, \varphi_{1}, \varepsilon_{1}, r_{1}$ 以外はすべて零となる ので, 式 (28) で定義した地盤ば放 $\tilde{k}_{d}$ は本報告の数值 計算には関与しなくなる.この結果, 井筒の変位や応力 は $X$ 軸に関しても対称あるいは逆対称なものとなる.

また井筒内部土のせん断抵抗, 式 (31), は次の継手 の剛度と同じ効果を与え, 一般には継手剛度に比べ無視 し得るものと思えたので, 式 (31) の $\tilde{G}$ は零とした.

b) 継手のせん断剛度 $G_{J}$ と回転ばね $k_{\varphi}$ 継手のせん断剛度に関する実験データは数少なく,こ れについても確定的な数值を得るに至っていないが，本 報告では $\phi 165.2 \times 7.1$ の継手管を用いた試験報告 ${ }^{12)}$ 
参考とした。この試験報告では $G_{J}=120000 \mathrm{t} / \mathrm{m}^{2}$ 程度 の值が得られているが，これは継手内のモルタル充填が 良好な室内実験の值であるので，この值の $1 / 2$ を基準モ デルの継手のせん断剛度としたただし，上記の継手管 と太さが異なる場合は, 継手管の内径に剛度は比例する と仮定した。

一方，図一4 に示すような継手モーメント伝達能力に ついてはまったく資料がなく，本報告では継手部の回転 ばね $k_{\varphi}$ は零として扱う.

c）井筒周長線の伸張変形剛度 $E_{s}$

剛度 $E_{s}$ は式 (46) で定義されるが，これは図一5に 示すように，矢板鋼管自体の断面変形に対する剛度であ る.

この矢板本管の断面変形には本管内の土砂なども抵抗 すると考えられるので，明確な根拠はないが矢板本管を リングとして計算した $E_{s}$ の 10 倍の值を用いた．ただ し，継手管内にはモルタルが充填されて抢り，継手にゅ るみはないことを前提とする。

\section{d) 矢板の断面定数}

式 (43) で定義した矢板の断面定数のうち, 純㸚じり 定数 $J_{s}$ 以外のものには継手管の断面も含めて断面定数 の計算を行ったが，継手管は開断面であるので $J_{s}$ の計 算には矢板本管のみを有効とした。

e) 頂 版

頂版は剛体として扱う。また，頂版と矢板は頂版下面 位置で剛結されているとする。

\section{（2）基準モデルの計算結果}

以上の条件のもとに計算した結果を 図一10 に示す. グラフの縦軸は井筒の長さであり，変位や応力の井筒の 長さ方向の分布を示すものである. 図一10 (a) は $Y$ 軸 方向の矢板の水平変位であり，図中の No. は図一9 に 示す矢板の番号である.また，上端の数值は頂版下面の

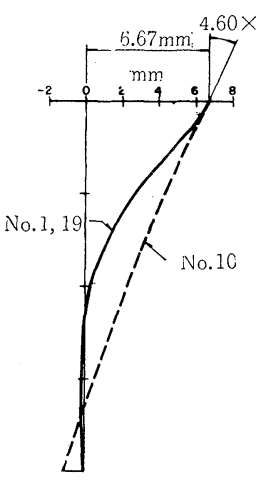

（a）矢板の水平変位
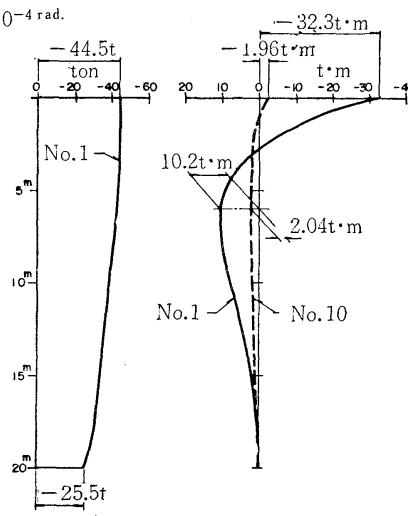

(b) 矢板の軸力 （c）矢板の曲げモーメント(d）継手のせん断応力

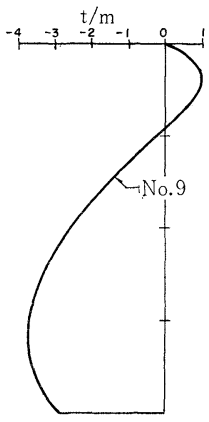

水平変位と回転変位であ る.このグラフから， 井筒前背面の矢板 No. 1 と 19 はかなり弯曲して いるのに対し, 井筒側面 の矢板 No. 10 は剛体的 な変位を示していること がわかる.これは，この 例題では周長線の伸張変 形剛度 $E_{s}$ が低いため, 井筒前背面の大きな地盤 反力をアーチ作用により 側方へ伝達する効果がな

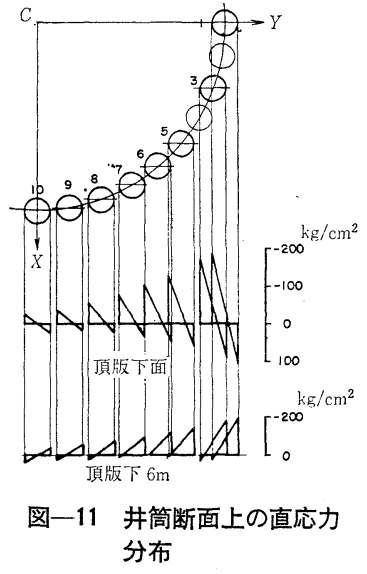

く, 井筒前背面の矢板は単一杭のように働き, これに対 乙井筒側面部の矢板は継手のせん断剛度により合成され た荷重と平行な方向の壁として剛に働くためである.図 -10 (c) は, 荷重方向と直交する軸まわりの矢板の曲げ モーメントを示すが，頂版との結合部において中間部と 異符号の拘束モーメントを生じている.このことは載荷 試験でも観測されているが，指針 ${ }^{11}$ の計算法では表わせ ないものである。また，井筒断面上での直応力分布を， 頂版下面位置とそれより $6 \mathrm{~m}$ 下方位置について 図一11 に示すが，従来実測されているような鋼管井筒の応力特 性をよく表わしている.

图一10 (d) は継手 No. 9 (矢板 No. 9 と 10 の間の 継手）のせん断応力 $q$ を示す.

\section{（3）比較計算}

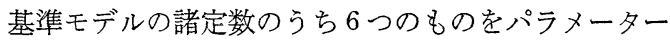
に選び，それらを1つ1つ值を変化させて計算を行い， それに伴う変位や応力の変動の具合を調べたのが 図一 12 である．その縌軸は変位や応力を示すが，すべて基 準モデルの対応する変位や応力との比で表わしてある.

横軸は対象に選んだパラメーターを示す が, 周長線の伸張変形剛度 $E_{s}$ 以外はす べて基準モデルの定数との比で表わして ある.すなわち，横軸に（）/）。表 わしてあるのがそれで（）は対象と したパラメーターの值であり，分母の （）。は比をとるのに用いた基準モデル の定数である.

グラフ中の矢板の軸力は矢板 No. 1 のものであり，矢板の曲げモーメントは グラフに示してあるように矢板 No. 1 と No.10 のものである.また，たとえ ばグラフ中に “No. 10 (中間)” と記して あるものは，矢板 No. 10 の中間部の正 


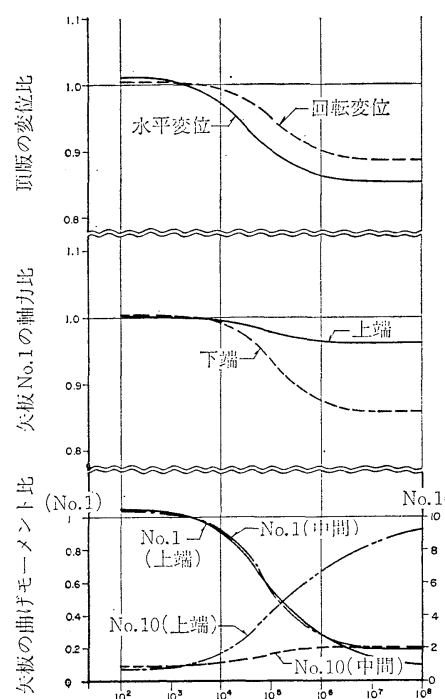

(a) $E_{s} t / \mathrm{m}^{2}$

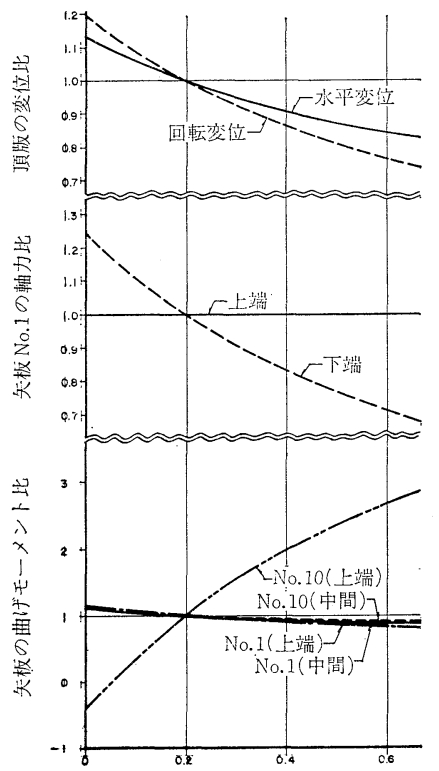

(d) $k_{z}$ と $k_{n}$ の比 $\left(k_{z}\right) /\left(k_{n}\right)_{0}$

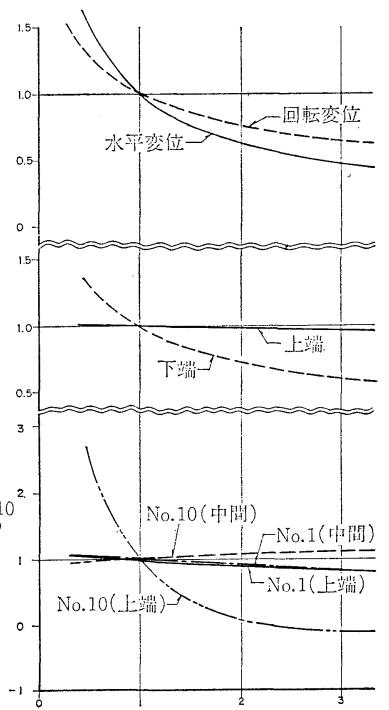

(b) 地盤反力係数刀比 $\left(k_{n}\right) /\left(k_{n}\right)_{0}$

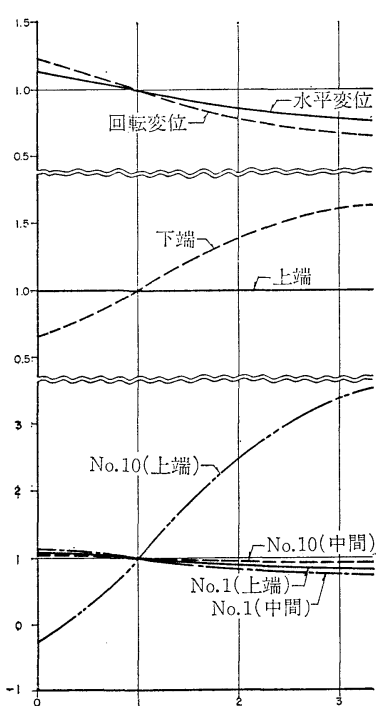

(e) 呧面地盤バネの比 $\left(K_{V}\right) /\left(K_{V}\right)_{0}$

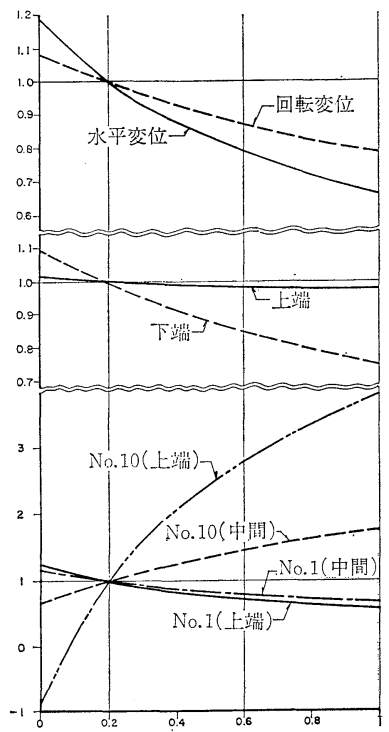

(c) $k_{s}$ と $k_{n}$ の比 $\left(k_{s}\right) /\left(k_{n}\right)_{0}$

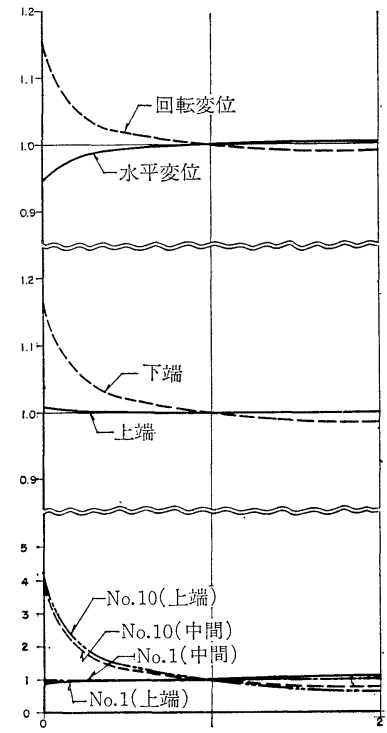

(f) 継手洽度の比 $\left(G_{J}\right) /\left(G_{J}\right)_{0}$

\section{図一12 井筒定数と变位, 応力の関係}

の最大曲げモーメントである. 図一12 (a) から, 伸張変 形剛度 $E_{s}$ が増すにつれ前面の矢板 No. 1 の負担が減 り側面の矢板 No. 10 の負担が増していくことがわか る.そのほか, 継手のせん断剛度の効果であるが, 図一 12 (f) をみる限りでは矢板 No. 1 の曲げモーメントに はほとんど影響ないようにみえるが，それは前にも述べ たように基準モデルの周長線の伸張変形剛度 $E_{s}$ が小さ いため, 前面の矢板は単一杭のように㗢いてしまうこと による． $E_{s}$ の值が大きくなり，アーチ作用による井筒 の周方向への地盤反力の分散作用が強まれば, 矢板 No.
1 にも継手のせん断剛度 $G_{J}$ の効果が矢板 No. 10 と 同様に生じてくる.

\section{9. 実物載荷試験への応用}

前章ではかなり大胆に諸定数を仮定して数值計算を行 ったが，本報告の計算法は定性的には鋼管井筒の挙動を 表現できるものであったと思う.この章では 図一13 に 示す 4 例の実物載荷試験- $\mathrm{A} \sim \mathrm{D}$ に適用して, 定量的な 面での比較を行う。 


\section{（1） 諸定数の決定}

諸定数の計算は基本的には前章と同じであるが, 多少 の変更や条件の違いもあるので，以下に相違点のみを示 すことにする.

i ） 矢板本管内にコンクリートが充填されている場 合，コンクリート断面は全断面有効でかつ完全に鋼管に 合成されているとする．またコンクリート充填区間の周 方向の伸張変形剛度 $E_{s}$ は, 前章で決めた一般部の值の 100 倍と仮定する（ただし，載荷試験-D では一般部， コンクリート中詰部ともにさらに 10 倍高めた).

ii）頂版と矢板が頂版下面で十分に剛結されている とはいいがたいと思えたので，計算上は実際の頂版下面 から $1 \mathrm{~m}$ 上を頂版と矢板の剛結点として計算を行った.

iii）地盤の変形係数は $N$ 值以外汇測定值も参照して 決めたが，その後の扱いは前章と同じである.ただし， 式 $(54 \cdot \mathrm{b})$ に対し，ここでは次のように仮定する.

$$
k_{s}=k_{z}=0.4 k_{n}
$$

その他の相違点や特記事項については以下に記す。

〔載荷試験- $\mathrm{A}$ : 雨天岸壁のクレーン基礎〕〕

井筒の下方 $15 \mathrm{~m}$ は地中に打ち込まれ ているが，その上方注海水中に突出して いる. 突出部は井筒の中も土砂詰めされ ているが，この部分に地盤ばねは一切考 えない。また継手のせん断剛度はモルタ ル処理区間については前章と同様に $G_{J}$ $=60000 \mathrm{t} / \mathrm{m}^{2}$ とするが，無処理区間に ついてはその $1 / 5$ と仮定した.

〔載荷試験-B：サイジングプラントの 基礎 ${ }^{8}$ 了

一般に脚付とよばれるものであり, 脚 部においては井筒部の矢板が 1 本おきに 抜けた断面となっている。この脚部を表 現するために，計算上は矢板本数を井筒 部と同じにする代わりに矢板断面定数を $1 / 2$ としたほか, 継手のせん断剛度 $G_{J}$, 伸張変形剛度 $E_{s}$ および矢板の純ねじり 定数 $J_{s}$ は零とした. また，この井筒は 他のものと継手構造が違い，継手のせん 断剛度はモルタル処理区間と無処理区間 でそれぞれ $G_{J}=10000 \mathrm{t} / \mathrm{m}^{2}$ と $1000 \mathrm{t} /$ $\mathrm{m}^{2}$ と仮定した.

〔載荷試験- $\mathrm{C}$ : 道路高架橋の基礎9 〕

〔載荷試験 $-\mathrm{D}$ : 東北新幹線高架橋の基 礎10)

図一13 (c)，(d) に示すようにいずれ も矢板本管内に途中までコンクリートが
中詰されているが，継手のモルタル処理は井筒のほぼ全 長にわたり行われている，ただし載荷試験-D では井筒 先端部 $2 \mathrm{~m}$ には継手管がないので, 継手のせん断剛度 $G_{J}$, 伸張変形剛度 $E_{s}$ および矢板の純ねじり定数 $J_{s}$ は 零とした。 また，継手構造は載荷試験-A と同じである ので，その剛度も載荷試験-Cではそれと同じとしたが， 載荷試験-D では文献 11）に報告されている継手のせん

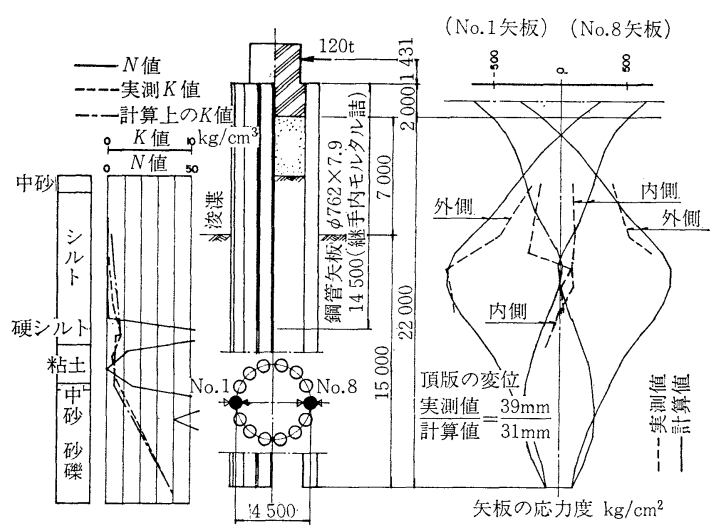

載荷試験一 $\mathrm{A}$ 川崎製鉄（株）水島製鉄所 雨天岸壁の基礎

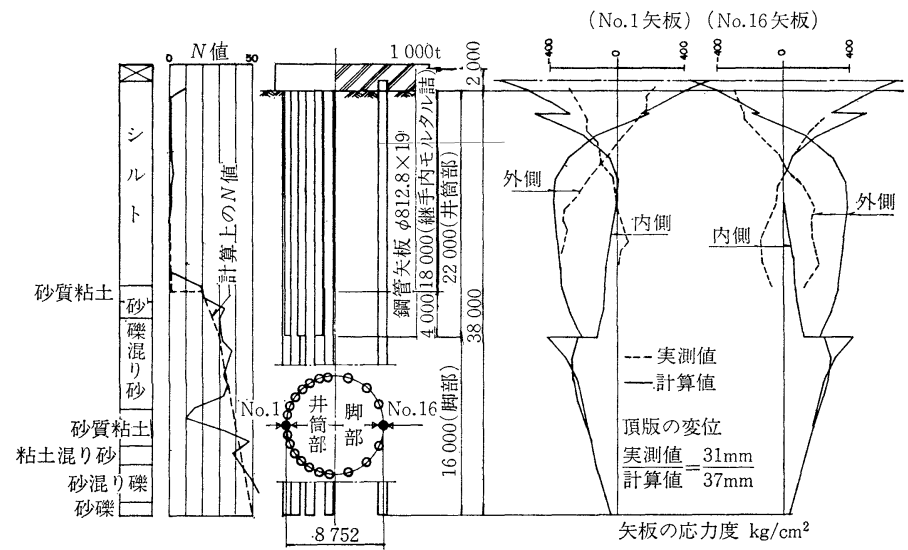

載荷試験一 $\mathrm{B}$ 日本鋼管（株）福山製鉄所 サイジングプラント基䃈

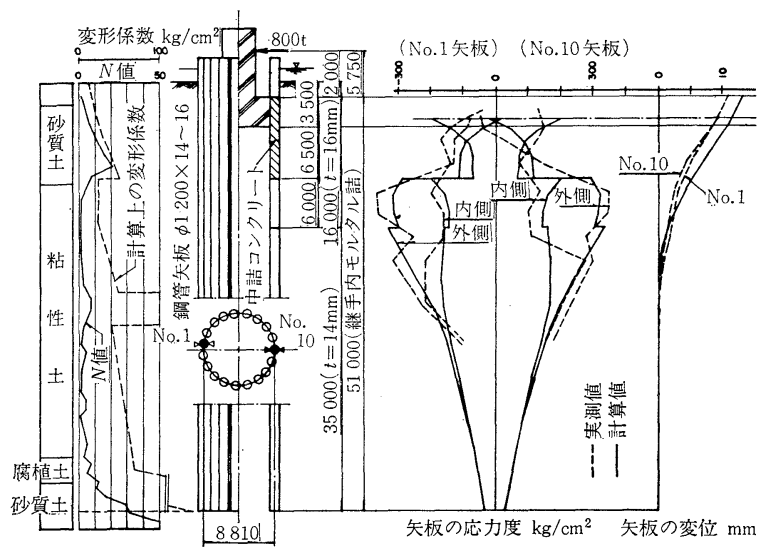

載荷試験一C 首都高速道路公団 BT 251 工区高架橋基礎 


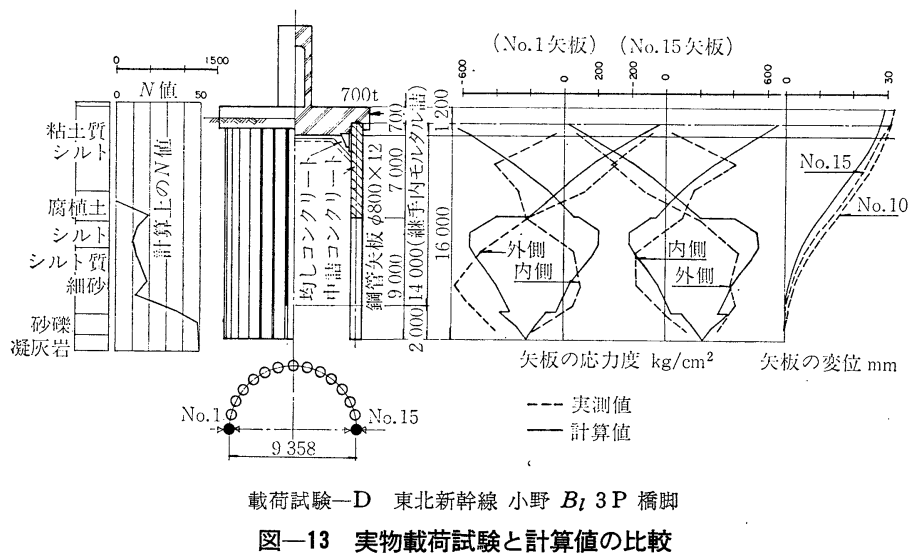

内の模型実験では地盤圧縮部の矢板応力 が引張部に比べ顕著に大きくなる ${ }^{2) \sim 4}$.

そのほか, 図一13 に示すように矢板 の頂部には杭基礎と同様の拘束モーメン トが生じ, 矢板の円外の応力度は地中部 に向からにつれ反転し交差する．このよ うな状態は，単一捧に置き換えて計算す る指針 ${ }^{1)}$ の計算法では評価できないもの である。

\section{0.あとがき}

実物載荷試験との比較によって示した
断耐力 $\left(q_{u} \fallingdotseq 20 \mathrm{t} / \mathrm{m}\right)$ を越えるせん断応力 $q$ が計算され るため, それを越えないように井筒の上方約 $2 / 3$ の区間 について継手のせん断剛度を 1/6〜1/3 程度に落として 計算を行ったものである.

\section{（2）計算結果と若干の考察}

上記の載荷試験における測定值と計算值を 図一13 に 示す. 各例とも応力度 は井筒前背面の矢板の $\nabla$ 印を付 した点に着目したものである. 頂版下面近傍の矢板応力 の測定值をみると, それには計算外の付属物（頂版下の 均しコンクリート, 頂版と矢板の結合金物あるいは載荷 試験-B では頂版下 $2 \sim 3 \mathrm{~m}$ には矢板内に中詰コンクリ 一トがあると予想されるなど）の効果が現われて測定值 が不自然に小さくなるなど測定值に乱れのあるものがあ るが，この点を除けば，定性的にも定量的にも計算值は 鋼管井筒の挙動を比較的よくとらえていると思う．ただ し，鋼管井筒の性状を支配する諸定数についてはいまだ 不明確な点が多分に残されているのが実情であり，これ まで記してきたように，わずかな資料をもとに多くの定 数を推定によって定め計算を行ったものである.そこで は，実物載荷試験結果を多分に参考として，それに合う ように諸定数の算定法を推定した面も多分にある.

たとえば, 本報告の数值計算では地盤ばねの強度分布 を井筒の周方向に一定としたが，それはケーソン基礎の 設計 ${ }^{11)}$ のよう地盤圧縮面にのみ地盤ばねを仮定すると そこの矢板にのみ大きな応力が計算され，実物載荷試験 の結果に合わないことによる.すなわち，実物載荷試験 では井筒前後の矢板応力に有意な差が認められず, 井筒 前後の矢板に対する地盤の抵抗に目立った差はないこと による、これはたとえば載荷試験-Cのように細長い井 筒を考えるとき井筒内部地盤が水平変位に抵抗するとは 考えられないことから，地盤中の静止土圧によって井筒 背面の地盤引張部にも引張ばね的効果が生ずるためであ ろ ${ }^{13)}$. その証拠に, 静止土圧のほとんどない浅い土槽 ように本報告の計算法は鋼管井筒本体の性状を比較的よ く表現し得るものであったと思5。しかし, 本報告では 三次元的広がりをもつ地盤を地盤ばねに置き換えて計算 しているので, 主要な構造要素である地盤の耐力機構に ついては言及できるに至っていない. わずかに, 実物載 荷試験との比較によって地盤作用の概略的なものを推論 しただけである、鋼管井筒ではケーソンと違って井筒内 部地盤も, 井筒が太短くなるにつれ, 水平抵抗に関与し てくるであろうし，また図一12 (c) で示したように地 盤の垂直抵抗 $k_{n}$ とせん断抵抗 $k_{s}$ の比は矢板応力にか なり影響する. これらの事柄を解明するためには, 地盤 を本来の三次元体として扱ら必要があると考えており， 今後は本研究を基礎として地盤の耐力機構にも言及して いきたいと思っている.

謝辞：本報告の作成にあたり，首都高速道路公団 神奈川建設局 矢作 枢氏ならびに建設省土木研究所 塩 井幸武氏から有益な示唆をいただいた. また, 載荷試験 データの収集に際しては多くの方々に労をとっていただ いた. ここに深く感謝の意を表わす次第である.

\section{参 考 文 献}

1）矢板式基礎研究委員会 : 矢板式基礎の設計と施工指針, 1972.

2) 嶋 文雄 - 後藤尚男 - 松浦 伦-吉倉敬治 : 鋼管矢板井 筒に関する模型実験的研究, 土木学会第 21 回年次学術講 演会講演概要集, III-112, 1966.

3）笹戸松二 - 山崎真喜雄 - 江見 晋 - 前原 博 : 矢板式基 礎の構造特性に関する模型実験, 橋梁と基礎, Vol. 10, No. 4, 5, 1976.

4）矢作 枢 - 岡原美知夫 -千野繁次 - 山本洋司 : 矢板式基 礎の模型実験に関する報告, 第 12 回土質工学研究発表会 講演集, 1977.

5）木寺謙爾・長岡弘明 - 島岡久寿 - 小間憲彦 : 鋼管矢板井 筒静的水平抵抗の有限要素解析, 土木学会論文報告集, No. 259, 1977.3.

6）川上賢司 - 大久保忠良・駒田敬一 - 岡原美知夫 : 矢板式 基礎と水平力に対するその構造特性, 土木研究所資料, 第 1034 号, 昭和 50 年 3 月. 
7）肱黒和彦・富永真生・新村和規：鋼管矢板 ウェルによる 海中ピアーの施工例, 第 17 回橋梁, 構造工学研究発表 会, 1970 .

8）藤田圭一・山口靖紀・木寺謙爾・島岡久寿・小間憲彦： 鋼管矢板井筒基礎の施工および水平載荷試験, 土と基礎, Vol. 21, No. 12 .

9）徳良賢一・根本 洋・手塚茂樹 : 鋼管矢板井筒基礎の実 物水平載荷試験, 土木学会第 32 回年次学術講演会講演概 要集, III-300, 1977.

10）日本国有鉄道仙台新幹線工事局：小野 $\mathrm{B} 13 \mathrm{P}$ 載荷試験
鋼管矢板井筒水平載荷試験の解析報告書, 昭和 53 年 3 月.

11）（社）日本道路協会：道路橋示方書 $\cdot I V$ 下部構造編，昭和 55 年 5 月.

12）駒田敬一 - 山川朝生 - 岡原美知夫 : 矢板式基礎の構造特 性（第 1 報)，土木技術資料，17-2，1975.

13）海野隆哉: 連続地中壁を用いた函型剛体基礎, 土木学会 誌, Vol. 65, 1980.4.

(1980.7.3 • 受付) 